\title{
Beyond Financialisation: The Need for a Longue Durée Understanding of Finance in Imperialism
}

\author{
Kai Koddenbrock, University of Frankfurt, Koddenbrock@soz.uni-frankfurt.de \\ Ingrid Harvold Kvangraven, University of York, York, ingrid.kvangraven@york.ac.uk \\ Ndongo Samba Sylla, Rosa Luxemburg Foundation - Regional Office West Africa, Dakar \\ ndongo.sylla@rosalux.org
}

We would like to thank Ilias Alami, Nick Bernards, Harry Cross, Florence Dafe, Tony Obeng, Wolfgang Streeck and Maria Dyveke Styve for helpful feedback and suggestions. All errors remain our own.

\begin{abstract}
One of the central premises of the literature on financialisation is that we have been living in a new era of capitalism, characterised by a historical shift in the finance-production nexus. Finance has begun to behave 'abnormally' towards production. It has expanded to a disproportionate economic size and, more importantly, has divorced from 'legitimate' economic pursuits. In this paper we explore these claims of 'expansion' and 'divorce'. We argue that although there has been expansion of financial motives and practices the 'divorce' between the financial and the productive economy cannot be considered a new empirical phenomenon having occurred during the last decades and even less an epochal shift of the capitalist system. The neglect of the needs of a self-centered economy has been the 'normal' and structural operation of finance in most of the former European colonies in the Global South during the last 150 years. We provide evidence to that effect with a longue durée study of the finance-production nexus in Senegal and Ghana. A main result of our empirical exploration is that an understanding of the historical developments of finance under colonialism is key for understanding how capitalist finance works globally. Such a de-centered perspective requires however a serious engagement with the concept and logics of imperialism.
\end{abstract}




\section{Introduction}

The concept of "financialisation" has come to play an important role in the field of political economy to describe a process of structural transformation in the central capitalist countries. Often, the debate implicitly suggests fundamental shifts in the evolution of the capitalist system globally. The various attempts to capture the meanings and implications of financialisation converge on two arguments. First, finance has reached a disproportionate economic size and dictates its laws to the productive sphere. Second, in a more descriptive vein, that no matter whether this is a cyclical or secular process, financial institutions, actors, motives and practices have expanded in recent decades. In this present article we call these the 'divorce' and 'expansion' views of financialisation.

Financialisation as 'divorce' 'carries a whiff of disapproval by tacitly suggesting a problematic relationship between finance and the rest of the economy' notes Costas Lapavitsas, one of the leading heterodox scholars on the topic (2013: 15). The editors of the recent Handbook of Financialization concur: They surmise that the financialisation literature starts from the idea of "finance as not subservient to the productive economy but as an autonomous realm that increasingly influences and even dominates other realms of society" (Mader, Mertens, van der Zwan 2020: 5). The more descriptive 'expansion' accounts of financialization from Greta Krippner (2005), and Gerald Epstein (2005), for example, focus on quantitative changes such as the size of the financial sector and the expansion of financial motives. This approach also accommodates Minskyian or Marxian readings on the inherent or cyclical expansion of finance on top of the productive sphere, akin to an 'intensification of what is already integral' (Christophers and Fine 2020: 25).

We argue in this article that despite the innovative analyses the financialisation literature has produced and the important trends it has highlighted, it has two major limitations that compromise its force in diagnosing the specificities of contemporary capitalism and the particular challenges currently faced by countries in the Global South. The first is that the literature, except for the Marxian and Minskyian accounts, has put its empirical focus mostly on the last four decades. This short and selective historical perspective inadvertently helps to exaggerate the novelty of the macro-structural realities described under the concept of financialisation (See Christophers 2015 for a similar argument). Phases of financial expansion marked by the assertion of the power of finance have indeed been characteristic of the long history of capitalism (Arrighi 2002) and are, for example, central for understanding the US economy since the early 20th century (Fasianos et al 2016). To avoid any ambiguity on this first critique, we do not argue that the present is just a repetition of the past and that there is nothing new under the sun. Our point is more modest: In order to detect continuities and ruptures, a longue durée historical approach is necessary.

The second and more profound limitation of the financialisation literature, mainly produced in Anglo-centric knowledge centres, is that it has predominantly focused on core capitalist countries in Europe and the US (see also Mader et al. 2020: 8) and has thus failed to work towards a fully global understanding of financial aspects of capitalism. The small proportion of research devoted to non-Western countries concerns the most important among them, and in particular those classified as "emerging economies", as in the works on "subordinate financialisation" by Bonizzi et al 2020; Kaltenbrunner and 
Painceira 2018; Lapavitsas 2013. The approach has often been to study the effects of the financialisation of core countries' on emerging economies or to measure to what extent emerging economies are displaying similar features of financialisation to those of the centre (e.g. Karwowksi and Stockhammer 2016). However, a focus on core countries, sometimes supplemented by a handful of "emerging countries", does not suffice to grasp the trends, continuities and shifts in the evolution of the capitalist system in toto. The perspective has to be de-centered. Beyond the study of how the financialisation of core countries affects the Global South, it is worth asking what a longue durée look at the finance-production nexus - the relationship between finance and production - from the perspective of peripheral countries can teach us regarding the realities currently described under the concept of "financialisation"?

Using such a de-centered perspective, this article challenges the view that finance has nowadays become 'abnormal' in its relations with production and the rest of society. This romantic perspective idealises the history of capitalist finance and, more generally, the logic of capital, which Marx rightly recalled came into being "dripping from head to foot, from every pore, with blood and dirt" (Capital, Vol. 1 chapter 31). To illustrate our argument, we focus on two West African countries, Ghana, a former British colony, and Senegal, a former French colony. Indeed, for these countries, finance's lack of interest in stimulating self-centered domestic production has been the norm from the end of the 19th century to the present. Interestingly, novel forms and instruments of financial expansion have appeared in both cases without however altering the pattern of divorce and extraversion.

Our thesis is that the divorce understanding of financialisation highlights nothing more than the 'normal' and structural operation of finance in the longue durée in these (post-)colonies. The emphasis in the literature on the novelty and disruptive impact of financialisation neglects how finance in the Global South has been operating over the last 150 years. This neglect reveals a lack of serious consideration for the relationships between finance and imperialism, an essential staple of Marxist literature (Bichler and Nitzan 2012). It corresponds to what Radhika Desai (2019: 1055) calls an "analysis of 'capitalism' shorn of imperialism".

We argue that the scholarship on financialisation needs to be embedded in a thorough analysis of the historical mutations and continuities of imperialism, conceived of as an enduring modus operandi of capitalism, rather than a particular historical stage of it (see for example Hudson 2003; Smith 2012, 2016; Patnaik 2001, 2018; Patnaik and Patnaik 2016). Indeed, a serious engagement from a Global South perspective with the logics of imperialism in the longue durée can help develop a superior and more comprehensive framework for analysing current financial developments worldwide. It also helps to tone down the claim of novelty often found in the financialisation literature.

To develop our argument, we briefly discuss in section two the financialisation literature and the extent to which it deals with colonial legacies and imperialism in the Global South. In section three we illustrate the dominant and extroverted role of (foreign) finance in Senegal, then in Ghana, since the onset of colonialism and trace how this role has endured in various ways throughout the contemporary period. Section four concludes. 


\section{Colonial legacies and imperialism: A blindspot in the financialisation literature}

Whether financialisation, viewed as an expansion of the financial sector, financial instruments and motives, is a secular or a cyclical phenomenon is an issue hotly debated. At stake is the degree of novelty and historical specificity of the financial developments of the last four decades in comparison with previous episodes of financial expansions. The Braudelian focus on the 'longue durée' has been a signature interest of Giovanni Arrighi (2010), for example, who criticised presentist and stage-ist thinking (e.g. Foster 2010, Bonizzi et al. 2020) ${ }^{1}$ to advance a more cyclical view of the finance-production nexus. According to Arrighi, the intensification of world trade and material expansion in the mid 19th century led to increased competition, lower profit rates, and a shift from production to finance. In fact, throughout the last 800 years, regional and global hegemons, from Genova to Holland to England, had tended to massively expand their financial sectors during phases of decline. In this longue durée approach, cyclicality instead of secular shifts or ruptures become the dominant evolutionary logic of capitalism. The focus on cycles helps to take claims to secular ruptures and shifts with a grain of salt and helps to zero in on decades of financial expansion. Expansion is one of the two core understandings of financialisation in the contemporary debate, as we argue above. Yet, even Arrighi's longue durée perspective tells us little about the second meaning of financialisation, the divorce of finance and domestic production within the evolving structures of imperialism.

The financialisation literature is the latest development in a long tradition of literature on finance and development (largely) ignoring or downplaying the role of colonial legacies, dating back to the classic economic analysis by McKinnon (1973) and Shaw (1973). Similar oversights can be found in the finance literature associated with the World Bank and the IMF, as well as the more recent financial inclusion literature (Bernards 2016). The nature of financial investments and the extraverted orientation of the financial systems in the colonies tended to benefit few, and mostly metropolitan actors (McKinnon 1973, Cain and Hopkins 1987, Narsey 2016, Hudson 2017, Patnaik 2017). This is not a new diagnosis, but it is one that has not been given adequate attention in the financialisation literature.

Acknowledging how colonialism shaped economies in the Global South and North in particular ways is an important starting point for understanding how economies operate today (as scholars of dependency have highlighted, see for example dos Santos 1972, Furtado 1970, Rodney 1972, Kvangraven 2020). The extractive nature of the colonial financial regimes and their impact on contemporary economies can also be found in Naoroji (1902), Prebisch (1939), Hudson (2017), Patnaik (2017), Bernards (2019), Alami (2020), Tilley (2020) among many others. In an African context, this has been documented by Nkrumah (1965), Amin (1974; 1976) and Pouemi (1980). Nkrumah analysed independent African economies through the lens of neocolonialism, with particular attention to the structure and limits of the post-colonial banking sector, with high foreign dominance and high banking concentration. Amin (1974) also observed

\footnotetext{
${ }^{1}$ Foster calls it the 'age of financialization' and Bonizzi et al. identify a 'new stage of mature capitalism.'
} 
the monetary problem of African countries in the working of their foreign-dominated banking system. He considered the banking sector to be characterised by its "inertia", that is its non-dynamic role in transforming peripheral African economies, but rather channeling funds primarily for short-term financing or state expenditures. These insights have not lost theoretical and empirical relevance when it comes to understanding how capital accumulation at a global scale and thus imperialism have historically shaped African societies.

Recently, authors have tried to specify the meaning and implications of financialisation for the Global South. ${ }^{2}$ That debate - pushed further in this special issue - about 'financial subordination' or 'subordinate financialisation' in the Global South (Bonizzi et al 2020; Lapavitsas 2013) recognises that history matters as all countries "have emerged out of the particular material conditions of the colonial, post-colonial and neo-liberal periods, each distinguished by characteristic conditions in the development of the world market" (Powell 2013: 112). This is a welcome contribution, as while we all know that "history matters", the history of the Global South has not yet mattered to a significant degree in the scholarship on financialization. Today, US Dollar dependency, international currency hierarchies and external vulnerability shape how dependence on the world market and financialisation transpire into emerging economies like Brazil or South Africa (Kaltenbrunner and Painceira 2018: 291). While these insights are crucial and helpful for understanding the constraints that developing economics face in the contemporary capitalist system, we assert that this literature has so far suffered from its lack of a longue durée perspective (but see Alami 2019). Indeed, the approach has been to study the effects and manifestations of recent financial developments in the Global North on the Global South rather than to examine what a longue durée approach of the finance-production nexus in the Global South can teach us about contemporary capitalism.

The implications of this lack of long-term perspective can be seen in the important works of Painceira and Lapavitsas. Painceira, writing from a Brazilian context on the 'effects of financialisation on developing countries' argues that "financialisation has [...] resulted in the absurd situation of the poor financing the rich in the world-economy" (2012: 212). These negative resource transfers, according to him, are a novelty, a qualitative shift, brought about by financialisation in the 2000s. Similarly, Lapavitsas (2013: 43) argued that financialisation in developing countries "has been driven by the opening of capital accounts, the accumulation of foreign exchange reserves, and the establishment of foreign banks". He also made the specific claim that:

\footnotetext{
"Capital flows have become strongly negative for developing countries on a net basis, that is, capital has flown from poor to rich countries. This has been a striking feature of international financialization, marking a profound difference with the period of imperialism..." Lapavitsas (2013: 246)

"As subordinate financialization has spread, even impoverished Africa has contributed to the net flow of capital from poor to rich countries." (Ibid: 249).
}

\footnotetext{
${ }^{2}$ For Latin America, see for example frank Cunha, Prates and Bichara (2010), Correa and Vidal (2012), Levy-Orlik and Ortiz (2016), Déniz and Marshall (2018), and Abeles, Caldentey and Valdecantos (2018).
} 
The above quotes are inaccurate from an historical perspective. Net resource transfers (net transfer of financial resources) from poor countries to rich countries have a long colonial and postcolonial history. In the case of Brazil, Kregel traces the beginning of external financing in the 1820s, and shows that since 1939 "the mobilization of foreign resources for development has produced [a situation where] developing countries [provide] net capital resource flows to developed countries." (Kregel 2004: 574). Narsey gives evidence that the sterling balances accumulated in London by British colonies were often higher than the investment they received from Britain (2016: 193). This was the case for its West African colonies, especially after World War II (see also Krozewski 2001). Recent decades have shown similar trends: "From the 1960s to the 1990s it is striking that for most of the period net resource transfers have not been positive, but negative. That is, financial resources have flown from developing to developed countries" (Kregel 2006:3). Net resource transfers from poor countries to rich countries have been an enduring fact, albeit geographically uneven, regularly lamented by the United Nations in its reports (United Nations 1992; 2011: 69-77; 2018: 43-44). For African countries, Boyce and Ndikumana (2011) have documented net transfers out of the continent from the 1970s and Kar et al. (2013) documented the same for 1980-2009.

While it is easy to get carried away by analyses of financialisation opening up new spheres and 'territories' for capital to extract value, it is important not to forget that this has precisely been, and still is, a major facet of imperialism under capitalism: the export and setting to work of capital beyond the initial homestead of the investor (Hobson 1902: 55; Hilferding 1910). Both processes are intricately connected as they seek to open up new frontiers for capital accumulation. Imperialism has always shaped the capitalist system in particular ways. It is not a period and can't be reduced to territorial conquest, as its forms are evolving. Imperialism at the age of colonialism, with competing metropolitan capitals, is qualitatively different from contemporary imperialism in which capital - under the form of "capital as finance" and of "capital-in-production" - has (i) become multinational/globalised, (ii) mostly oriented towards short term speculative activities in a context of (iii) a "muting of inter-imperialist rivalry"3 (Patnaik 2018: 63-64).

Despite its continued relevance, much social science literature is completely silent on imperialism, thus masking the power relations global economic processes are embedded in (Desai 2019, Foster 2019). As Foster (2019) puts it, the "silence over imperialism is not the aftermath of some intense debates where the scales tilted decisively in favor of one side; it is not a theoretically self-conscious silence." Indeed, despite the silence on imperialism in much scholarship on financialization and globalization, there's a pocket of scholars who point out that the concept is indeed as relevant as ever, if not more, in the context of international financialization processes (e.g. Borón 2005).

Indeed, in times of the 'great fragmentation of the firm' (Reurink and Garcia-Bernardo 2020), i.e. corporations sliced into myriad sub-entities across global value chains has made it possible for corporations to profit from regulatory arbitrage, transfer pricing, tax avoidance, as well as intellectual monopolies (e.g. Milberg 2009; Durand and Milberg 2020). These multinational (financial) corporations have economic interests in attempts to develop financial markets in developing countries through what has been called the "Wall Street-Consensus" (Rowden 2019; Gabor 2020). This involves the promotion of

\footnotetext{
${ }^{3}$ Increasing rivalry between China and the US may un-mute inter-imperialist rivalry in the medium term.
} 
public-private-partnerships (PPPs) and the development of local capital markets. As Gabor (2018) has put it, this consensus means prioritising asset management over development and industrialisation, as instruments created through market-based finance have the possibility of meeting demands generated by international investors in the wake of low interest rates in the Global North (see also Braun 2016). As we will see, these global financial developments seem to strengthen the lasting 'divorce' pattern in the economic and financial systems of Senegal and Ghana.

\section{Finance in Imperialism in the Longue Durée: Senegal and Ghana}

Through the slave trade and colonialism, the West African territories currently known as Senegal and Ghana have been transformed into 'économies de traite', or 'trading economies' (Ki Zerbo 1957). This means that it was import and export trade, rather than larger scale production, that shaped the economy. Their financial systems still bear the footprint of this economic structure as they have been devised according to trade's functional needs. They make particularly interesting case studies as they help illustrate the general observations made by Amin (1976) from a Marxist lens and even McKinnon from a economic mainstream lens that during colonialism "organized banking served mainly expatriates who were engaged in developing exports of raw materials." (1973:69)

Senegal was the 'bridge head' of French colonialism in West Africa ('tête de pont', translated from Bellito 2001: 19) and Ghana played a similar role for British colonialism. In both of these cases, the "divorce" of financial from domestic production was the result of political as well as economic domination, especially of merchant capital (Banaji 2016). We substantiate this claim through a long durée approach. We show how production and finance were shaped in an extractive manner in the colonial and post-colonial periods and how after independence the governments of both countries strove to decolonise economic and financial structures. A reversal of these structures happened to some extent, especially in Ghana. But from the crisis of the 1970s onwards, these reversals came to be undone through liberalisation, privatisation and deregulation. In order to trace historical continuities and breaks, we focus below on the Compagnie Française de l'Afrique de Ouest (CFAO) and Anglo Gold Ashanti, two global companies epitomising the extractive nature of foreign capital during the colonial period as well as its ongoing mutations under contemporary capitalism. CFAO was recently sold to the Toyota Trading Corporation and Anglo Gold Ashanti has turned from British only to a more diverse ownership.

We selected these two countries in the belief that they are apt case studies helping understand how colonial domination implied a lasting divorce between finance and domestic self-centred production in West African "trading economies". To what extent our findings and conclusions could be applied to other parts of the continent having relatively different financial systems, like settler territories such as Kenya or the mining areas in Central Africa, is food for ongoing research. 


\subsection{Senegal}

\section{Foreign-dominated banking and merchant capital 1850-1960}

After serving as an important hub for the trans-Sahara trade for centuries, thanks to its privileged geographical location, Senegal entered a close direct trading relationship with Europe, and particularly France during the slave trade. Senegal became an official colony, ruled by an administrator sent from Paris in 1818 but reliance on domestic power structures remained high (Searing 1993: 164). After the official end of slavery in France in 1848, so-called 'legitimate commerce' increased and entailed a drastic increase in the volume of exports of mainly groundnuts until the 1960s (Hopkins 2020: 26). The growing groundnut export industry was mainly organized by a handful of trading companies - especially after the constitution of the AOF (Afrique Occidentale Française), the French West African federation grouping eight French colonies - with shifting degrees of support by the colonial administration and changing structures of domestic intermediaries.

The abolition of slavery in France gave birth to the French colonial banks. Based in Saint-Louis (Senegal), the Banque du Senegal was the only French colonial bank with a headquarters outside the metropolis. Created in 1853, it was the child of an indemnity policy by the French under Napoleon III to slave trading societies and traders (Amaïzo 2001; Rocheteau 1982: 26). Depending on the amount of slaves the French and Senegalese traders held, they were given shares of this new financial institution. Most of them then sold their shares to the trading companies (Alibert 1983: 19; Lydon 1997; Dieng 1982). The Banque du Senegal received the privilege of note issue with the main objective to "facilitate the exports of groundnuts from Senegal” (Róux 1950, quoted in Singh 2008: 319).

Like the other colonial banks in the French empire, the Banque du Senegal was to be submitted to two rules. First, banknotes in circulation could not exceed three times its metallic reserves. Second, its balance sheet could not exceed three times its equity (Lelart 1998:553-4). According to Alibert, the Banque du Senegal was initially not needed to play the role of credit creator and instrument of capitalist expansion because, among other factors, the large trading companies were their own banks, or could be financed by metropolitan banks, and were sometimes shipping bank notes from France to Senegal themselves (Alibert 1983: 54). The Banque du Senegal began to facilitate foreign exchange transactions, to grant short term credits related to export products; to export local savings to the metropolis; and to protect trading companies from indigenous competition (Dieng 1982). This functional role of the banking sector in the former French colonies in West Africa would be left unchanged even after independence in the 1960s. Its oligopolistic character would remain (Alibert 1983; Singh 2008: 318; Imam and Kolerus 2013: 19).

In 1901, the Banque de Senegal was replaced with the Banque de l'Afrique Occidentale (BAO) Based in Paris, the BAO united the functions of currency issuing bank, commercial bank and investment bank. The role of the French government increased step by step after the First World War (Alibert 1983: 75-76). At its birth, the BAO received $70 \%$ of its income from foreign exchange activities (Dieng 1982: 81). Like its predecessor, it was not at all oriented towards financing indigenous entrepreneurs and in diversifying the colonial productive structure. It had "the means of eliminating competitors or anybody who was a hindrance to the profits of the big companies" (Suret-Canale 1971: 188). The limited and skewed 
contribution of the banking sector was acknowledged by colonial authorities themselves. In a letter sent in 1917 by the governor of Senegal to the governor of the AOF it was written that: "Colonial banks [...] did not contribute adequately to the development of the colonies. They have not given the financial support, economic assistance and encouragement expected of them." (quoted by Dieng 1982:78; our translation)

This extraverted situation divorcing finance from self-centered domestic production did not change substantially over the coming decades. French commercial banks began setting up branches in West Africa starting in 1939 in Senegal with Banque nationale pour le commerce et l'industrie, to be followed by Crédit Lyonnais and Société Générale. In line with the trading economy logic, these banks would further amplify territorial disparities within the AOF as they became active mostly in coastal countries and regions rather than in the interior ones. In 1949 BAO devoted $92 \%$ of its resources to financing export and import activities (Dieng 1982: 69). In 1959, the BCEAO - the West African Central Bank - and its Central African counterpart became the last successors of the Banque du Senegal and BAO.

This particular organization of the banking sector mirrored the characteristics of French colonial investment which was small and dominated by merchant capital (Suret-Canale 1971:159-60). ${ }^{4}$ In 1940, $50 \%$ of French investment in AOF occurred in trade, with industry playing a more limited role (Suret-Canale 1971: 166). French metropolitan industrialists, for example the cotton textile sector (Boone 1992: 35-39) and the flour millers (Singh 2008: 178), did not want competitors in the colonies. Their expectation was rather to obtain strategic raw materials in exchange for their industrial products. That was the deal they had with the dominant French colonial trade companies such as Compagnie Française de l'Afrique Occidentale (CFAO) and the 1906-founded spin-off and partly Swiss-owned Société Commerciale de l'Ouest Africain (SCOA). These companies relied on the protection granted by both the colonial government and the colonial banking sector to suppress local competition, thus keeping domestic production from developing.

While Senegalese traders had had enough operating space to pursue their own business strategies in the 19th century, this changed with the imposition of colonial rule and a deeper penetration of colonial business into the countryside following the constitution of AOF (Sow 1992: 260; Bonin 1987; Moitt 1989: 27). Private capital from Bordeaux and Marseille was used to set up the first big trading companies such as the CFAO. These trading houses massively expanded their operations both in Senegal and the rest of West Africa over the decades and allow us to analyse the transformative impact of what we call 'foreign direct investment' today.

The CFAO was the largest and most successful French trading company that entered the Senegalese market, with a capital of 30 million Francs in 1887 (Singh 2005: 429). It mainly imported textiles, while being highly dependent on Senegalese intermediaries and peasant labour force to harvest its main export product, the groundnut (Bonin 1987: 67). Over time, CFAO sought to increase direct control, cut out intermediaries with the help of infrastructure investments by the French colonial governments and became 'notorious' in Walter Rodney's term for its capacity to siphon off profits (1972: 155).

\footnotetext{
${ }^{4}$ Between 1870 and 1936, Ghana and Mozambique received individually more foreign investment than all the territories of the AOF combined. The latter represented only $4 \%$ of the total private capital exported to sub-Saharan Africa during this period (Frankel 1938; Dresch 1946, 1952; Suret-Canale 1971: 161; Singh 2008: 428).
} 
Apart from tacit oligopoly agreements to keep colonial product prices down and the ability to exploit price differentials - for example cement that was sold in "Marseille at 798.35 francs CFA was, on the average sold at Dakar for 3,035 francs CFA" in 1946 (Suret-Canale 1971: 185), CFAO's success was built on the "pyramidal structure of the trading economy" (Sow 1992: 297, our translation) that came with its operations. ${ }^{5} \mathrm{CFAO}$ at the top advanced credit to their network of intermediaries and thus made sure that the desired commodities ended up in their halls - and for very low prices (Suret-Canale 1971: 186). Furthermore, debts to merchants played a central role in maintaining control over cheap groundnuts and the restriction of other sources of credit for local development was vital to the interests of merchant firms (Boone 1992, Bonin 2008, Banaji 2016). Indeed, merchant firms lobbied aggressively against private property in land, which was detrimental to the possibility for farmers to obtain credit for agricultural production (see Bernards 2019 on this point and also on the continuity and renewal of the logics of colonial finance in rural Senegal). In this way, the colonial banking system worked in tandem with colonial business to maintain the divorce between finance and domestic production.

During the course of World War II, in a context where their ties with the metropolitan economy were severed, CFAO and the trading companies started to be involved reluctantly in industrial production in the colonies, such as the fat processing industry (Coquery-Vidrovitch 1975). The dominance of trading companies increased further after World War II. The relative importance of both SCOA and CFAO is visible in the fact that, in 1946, their market capitalisation at the Paris stock exchange represented $84 \%$ of all listed corporations in French West Africa (Dresch 1946: 62).

In the 1960s, Senegal's independence and legal sovereignty led CFAO to adapt, including paying higher wages and higher tax rates on its profits (Coquery-Vidrovitch 1975: 616). Reacting swiftly, CFAO disengaged from the factorerie system reaching far into the hinterland, i.e. running their own small collecting posts along the peanut trading routes which had at the time driven Senegalese traders out of business, and created legal subsidiaries conforming to new national laws. CFAO increasingly operated as a holding company (Suret-Canale 1987: 92; Bonin 1987).

\section{Shifts and colonial continuities after independence}

In the post-independence era the structural operation of finance in Senegal, in particular the monetary and banking system, has remained remarkably unaltered despite a diversification of financial instruments used and of the country's economic relationships away from France over the last few decades.

As for most of the former French colonies in sub-Saharan Africa, except for Guinea, Senegal obtained its independence in 1960 on the condition that they signed "cooperation agreements" with the French government covering sovereign domains such as the currency, external trade, raw materials, diplomacy and the armed forces. This meant for the new Senegalese Republic to surrender its formal sovereignty in

\footnotetext{
${ }^{5}$ Note that this was one of the important factors to consider when analyzing the profitability of imperialism in Hobson's classic study: "the value of our foreign markets must rightly be considered to be measured, not by the aggregate value of the goods we sell abroad, but by the superior gain from selling them abroad as compared with selling them (or corresponding quantities of other goods) at home" (1902: 30)
} 
all those areas to France, including currency and exchange rate management (Pigeaud and Sylla 2018). This is a significant difference with Ghana.

Thus, Senegal and the other members of the West African Monetary Union (WAMU) did not have an exchange control policy independent from the French one until the end of the 1960s (Guillaumont and Guillaumont 1972). Likewise, the Central Bank BCEAO's headquarters was located in Paris with its foreign reserves being held at the French Treasury only in a devaluation-prone French franc. The BCEAO was moved to Dakar in 1978 with its staff "Africanised". The "Africanisation' of the BCEAO and other reforms to monetary management were concessions at that time from the French government, following protests by some West African countries who criticised the monetary and banking system for its limited contribution to domestic financing (Sylla, forthcoming). However, monetary policy has continued until today to be controlled by French representatives sitting in the organs of the BCEAO. ${ }^{6}$ This has contributed to restricting the degree to which monetary policy could be used to spur domestic production.

In this particularly restrictive setting, the Senegalese government tried in the two decades following independence to increase self-reliance. Development banks were founded and credit to the broader economy became more available (Amin 1973: 6; Singh 2008; see figure 2). From 1979 onwards, the Senegalese government, at the behest of an "Africanised" but still French-controlled BCEAO, eased refinancing ceilings on commercial bank credit (Sow 1992: 290). 90\% of credit to small and medium enterprises could be refinanced, $75 \%$ of agricultural production credit, $65 \%$ of industrial production credit and $50 \%$ for others. In colonial times, only short-term advances were available to Senegalese entrepreneurs (Sow 1992: 276) production credit, and import/export credit was only available to the dominant economic French and Syro-Lebanese classes. For example, in 1975, of 15 billion CFA franc in credit by commercial banks, only 1 billion went to Senegalese companies (Sow 1992: 294).

Contrary to what independence leaders had hoped, the shift from the colonial and private trading system to a state-owned one did not put an end to the exploitation of the peasantry. The economic surplus previously siphoned off by trading companies were now partly appropriated by the Senegalese State (Amin, 1973:12; Founou-Tchuigoua 1981). The postcolonial decades witnessed the decline of the peanut economy from two thirds of exports in 1960 to $20 \%$ in 1990 and 'diversification' into fish, tourism and phosphates (Gellar 1995: 60).

Senegal's independence would also consolidate other trends already noticeable after World War II, a period marked by an expansion of capital exports, and especially from non-French investors and from the French metropolitan government. While the public subsidies from the metropolis to the colonies had been historically low in the first half of the 20th century, they increased drastically between 1947 and 1958 (Huillery 2014:6, Singh 2008: 432). French aid helped to compensate to some extent the huge outflows of private capital income, as French companies repatriated their profits systematically, with only a small proportion being reinvested in Africa (Singh 2008: 380-383). This pattern whereby the structural deficits of the income and trade balances are attenuated by official development assistance (ODA) would be one

\footnotetext{
${ }^{6}$ The grandiloquent announcement of the ECO as a replacement for the CFA and the withdrawal of French representatives from BCEAO organs has, to our knowledge, not taken place yet since the announcement in December 2019.
} 
of the major characteristics of Senegal's trajectory until the mid-2000s (see figure 1). Three changes occurred however.

\section{Figure 1: Selected balance of payments indicators for Senegal 1970-2018 (\% GDP)}

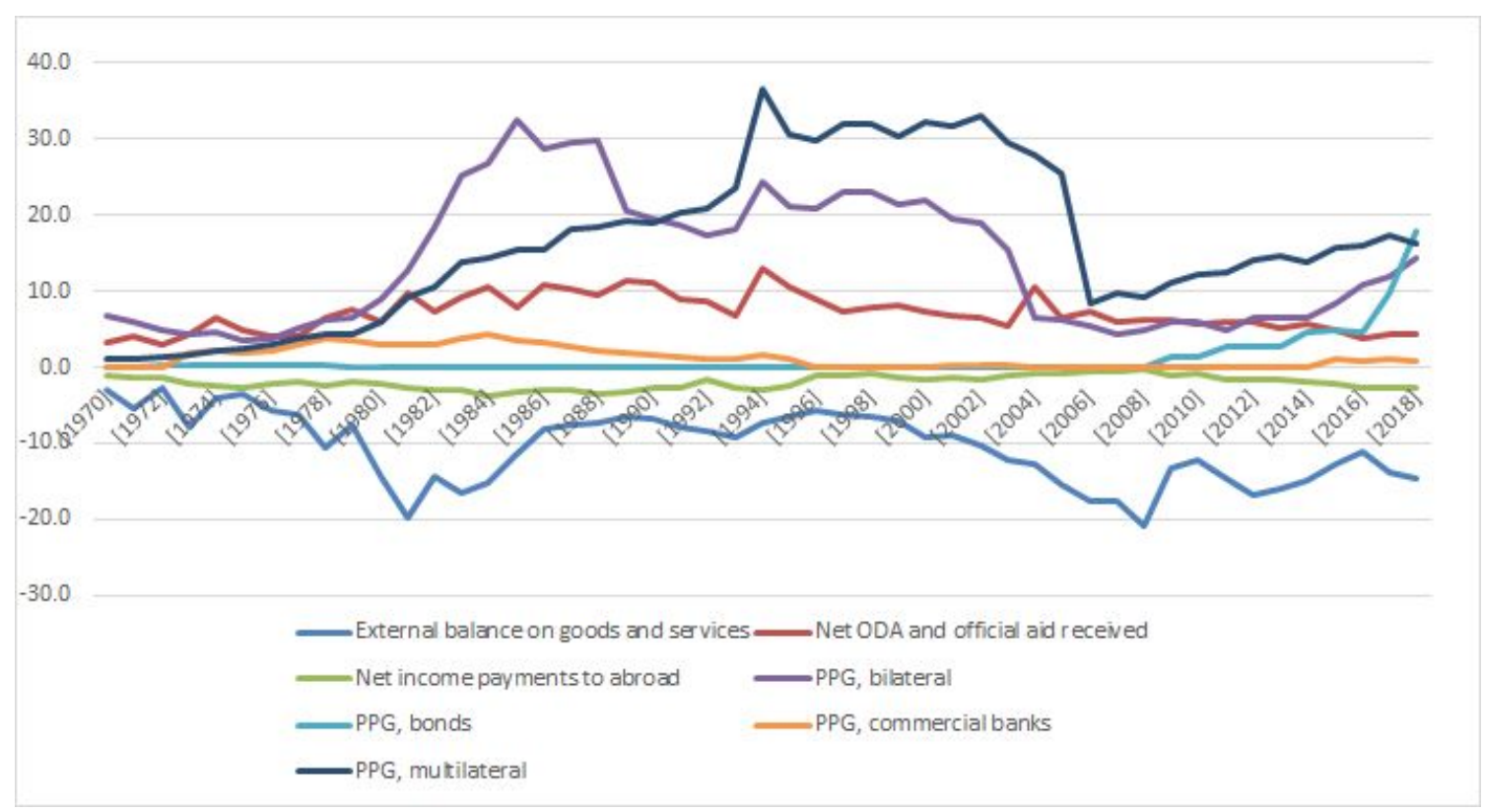

Source: World Development Indicators, World Bank (PPG = Public and publicly guaranteed $)$

First, ODA would come more from sources other than France, reflecting the declining share of France in Senegal's trade. Second, ODA would decline relatively in favour of global sources of private foreign finance (debt in foreign currency, foreign direct investment and migrant remittances). Three, the partial cancellation of Senegalese external public debt - under the Heavily Indebted Poor Countries (HIPC) framework and the Multilateral Debt Relief Initiative (MDRI) - in the mid-2000s and the global liquidity conditions after the 2008 global financial crisis fueled a new cycle of growing indebtedness marked by a shift in the choice of debt instruments, namely the recourse to Eurobonds (Sylla and Koddenbrock 2019) rather than commercial bank loans as in 1970s (see figure 1). With this trend, we see the expansion and diversification of financial instruments to finance development in Senegal, as the proportion of official finance dwindled.

In parallel to these new kinds of offsetting capital inflows, Senegal's more state-directed economic phase begun in the 1960s would not last long. For a number of different reasons, including notably the decline of the groundnut sector, adverse terms of trade, the rise of non-performing bank loans, soaring global interest rates, corruption and public mismanagement, the Senegalese banking sector would end up in crisis in the late 1980s. Its restructuring in the framework of the Structural Adjustment Plan (SAP) of the IMF and the World Bank (Diouf 2002) led to tighter prudential banking rules, to the elimination of preferential interest rates and to a liberalisation of interest rate ceilings. It also led to the liquidation of public development and agricultural banks while the main affiliates of French banks were recapitalised 
(Boone 2005: 413; Parmentier and Tenconi 1996: 97-98). As one World Bank assessment of the impact of the SAP put it:

"Of all the reforms undertaken by Senegal in the 1980s, banking sector reform - in which 7 of the country's 15 banks were closed - must be considered the most successful reform. This achievement owed a great deal to the very active role of the BCEAO, whose views on bank restructuring were very close to those of the foreign donors involved in the operation." (Ranis 1994: 310-311)

The privatisation and de-Senegalisation of the banking sector would consolidate with the marked dominance of foreign capital. In 2018, the Senegalese government's share in the banking sector was less than $10 \%$ versus $2 / 3$ for non-nationals. Out of a total of 25 banks, the government only has shares in nine, mostly specialised banks. The emergence of Pan-African banks throughout the African continent has globalised domestic banking (Enoch et al 2015; Mecagni et al 2015). Senegal has not escaped that trend. The Senegalese branches of banks based in France have seen their market shares erode in the face of competition by bank groups from Morocco (Bank of Africa, Attijariwafa Bank), Togo (Ecobank) and Nigeria (United Bank for Africa), for example. In 2019, in terms of market share in the West African Economic and Monetary Union, Société Générale came second behind Ecobank (13.2\%). BNP Paribas occupied the $9^{\text {th }}$ rank with 4\% market share (BCEAO 2019: 47). However, the concept of "Pan-African banks" is misleading because it relies on the headquarter's location rather than on the structure of ownership and control. Take the case of Ecobank: While founded and officially based in Lomé, Togo, it is majority-owned by the Dutch Nedbank, Qatar National bank, the World Bank's International Finance Corporation (IFC) and the South African government-owned asset manager Public Investment Corporation at 21.2, 20.2., 14.1 and 13.5. \% respectively (Ecobank annual report 2019: 308).

With the diversification of its ownership, the Senegalese banking sector became less oligopolistic since the 2000s. But it is still heavily foreign-controlled. In 2012, according to the World Bank, foreign banks represented $83 \%$ of all banks operating in Senegal and they accounted for $94 \%$ of all bank assets (see table 2). Since the 2000s, there has also been an increase in financial depth: Financial deposits, which are essentially held by the banking sector, have doubled as a share of GDP (World Bank Global Financial Development Database). For a comparison to Germany, which is known to have a stronger connection between banks and the real sector, and the United Kingdom, which is known to be a global financial centre, see Table 2. Table 2 also demonstrates that both the amounts of foreign bank assets among total bank assets and the amount of foreign banks among total banks is extremely high in Senegal compared to Germany, and relatively high also compared to the UK (although the difference with the latter is smaller). Meanwhile, although domestic credit to the private sector as well as deposit banks' claims on the domestic non-financial sector to GDP has increased over the past two decades for Senegal, it is still extremely low compared to both the UK and Germany. Deposit banks' claims on domestic non-financial sector to GDP is a measure of productive lending to GDP and is an indication of to what extent the financial system is working to spur production. Again, there is a cyclicality to be observed, with the levels remaining extremely low throughout the period (for the UK, for example, this figure was $132 \%$ in 2017 , and the figure was $91 \%$ for Germany in the same year). 
Table 2: Key Banking and Financial Indicators

\begin{tabular}{|c|c|c|c|c|c|c|c|c|c|c|}
\hline \multirow{3}{*}{$\begin{array}{l}\text { Foreign } \\
\text { bank } \\
\text { assets } \\
\text { among } \\
\text { total bank } \\
\text { assets (\%) }\end{array}$} & \multicolumn{2}{|c|}{ Senegal } & \multicolumn{4}{|c|}{ Ghana } & \multicolumn{2}{|c|}{ United Kingdom } & \multicolumn{2}{|c|}{ Germany } \\
\hline & 2004 & 2012 & 2005 & & & 2012 & 2004 & 2013 & 2004 & 2013 \\
\hline & 56 & 94 & 57 & & & 69 & 9 & 14 & 5 & 13 \\
\hline \multirow{2}{*}{$\begin{array}{c}\text { Foreign } \\
\text { banks } \\
\text { among } \\
\text { total banks } \\
\quad(\%)\end{array}$} & 2000 & 2012 & \multicolumn{3}{|l|}{2005} & 2013 & 1996 & 2013 & 1996 & 2013 \\
\hline & 60 & 83 & \multicolumn{3}{|c|}{58} & 63 & 45 & 58 & 9 & 14 \\
\hline \multirow{2}{*}{$\begin{array}{l}\text { Domestic } \\
\text { credit to } \\
\text { private } \\
\text { sector (\% } \\
\text { of GDP) }\end{array}$} & 2000 & 2017 & \multicolumn{3}{|c|}{2000} & 2017 & 2000 & 2017 & 2000 & 2017 \\
\hline & 15 & 29 & \multicolumn{3}{|l|}{14} & 14 & 47 & 67 & 86 & 84 \\
\hline \multirow{2}{*}{$\begin{array}{l}\text { Deposit } \\
\text { banks' } \\
\text { claims on } \\
\text { domestic } \\
\text { non-financ } \\
\text { ial sector } \\
\text { to GDP }\end{array}$} & 2000 & 2017 & 1968 & 1990 & 2000 & 2017 & 2000 & 2017 & 2000 & 2017 \\
\hline & 15 & 36 & 15 & 4 & 5 & 26 & 108 & 132 & 147 & 91 \\
\hline
\end{tabular}

Source: World Bank Global Financial Development database

However, these minor improvements in financial depth do not translate into structural transformation for several reasons. First, within the WAMU banking loans are very unequally distributed. According to Imam and Kolerus (2013:6), the 50 biggest corporations operating in this monetary zone receive 1/3 of all bank loans. Second, as was the case during the colonial period, credits to the economy remain principally short term. In 2019, 44.2\% of bank loans in Senegal have a maturity less than a month and $76.7 \%$ have a maturity below 12 months. In 2006, the respective proportions were $48.8 \%$ and $80.6 \%$ (BCEAO 2020a:30; BCEAO 2012:49). As a matter of fact, 60\% of bank loans in Senegal serve to finance short term cash flow operations (BCEAO 2020a:9). Third, bank loans, short and long term, are mostly allocated to trade $(26.5 \%)$ to the detriment of the manufacturing industry $(13.9 \%)$ and, especially the agricultural sector (1.7\%) which employs the bulk of the labour force (BCEAO 2020b: Annex 57). Fourth, the slight decline of average nominal interest rates since 2014 (BCEAO 2020a:30) does not necessarily indicate diminishing borrowing costs. Fees and commissions are not included in the calculation of average effective interest rates by the BCEAO (2020a:10). However, they generate more income than interest on loans. From $33.7 \%$ in 2000 , non-interest income was estimated to account for $58.7 \%$ of the total income of the banking system in 2017 (World Bank Global Financial Development database). 
What is more, the monetary policy framework became more conservative, especially after the 1994 devaluation of the CFA franc and the subsequent import of the sound finance principles of the Maastricht Treaty. In 1999 the euro replaced the French franc as the new anchor to the CFA franc. In 2010, the BCEAO statutes were modified in order to assert its statutory independence and its focus on price stability (Pigeaud and Sylla 2018: 116-7). Moreover, WAMU member States could no longer be granted overdrafts by the BCEAO who since capped the refinancing possibilities for loans granted to States by domestic commercial banks (Koddenbrock and Sylla 2019). These latter two changes were thought of as measures to facilitate the development of the local currency bonds market, which was also perceived as an instrument allowing to solve the paradox of excess liquidity in an environment of underfinanced economies (Doumbia 2011; Sylla and Koddenbrock 2019).

Expansion of financial instruments has taken place, but it has not made the financial markets more oriented towards domestic production. The regional stock market - the BRVM - was created in 1998. The local currency bond market component, mostly dominated by trade in sovereign securities has increased substantially in size since the mid-2000s (Sy 2007; Magnan-Marionnet 2016), but its development is limited by the conservative monetary framework of the BCEAO which must defend a fixed peg and to that end must maintain a level of foreign exchange that backs its monetary base (Laskaridis and Toporowski 2016).

\subsection{Ghana}

The phase of economic and financial expansion with the British Empire at the helm that took place over a hundred years ago was crucial for the shaping of financial and economic systems in the British colonies. We call this phase the City Consensus because of the central role of the strong links between the British colonial government, British industrialists and British finance in the City of London at that time (Cain and Hopkins 1987). Between 1865 and 1912, the City of London was extremely extroverted (ibid 1987, Rönnbäck and Broberg 2019). In this period, British savings that had previously been placed in domestic assets (government stocks, railways or mortgages) were moved into investments abroad, as the returns were higher (Cain and Hopkins 1987). Thus, Britain became the world's major exporter of capital between 1870 and 1914, with most investment going to the United States and the "dominions" (Canada, Australia, etc.) in contrast with colonies such as India (Rönnbäck and Broberg 2019:25-27). ${ }^{7}$

\section{Colonization and Decolonization: The Imperial Orientation of Production and Finance}

While gold and cocoa were important exports during the colonial era, gold played a unique role. ${ }^{8}$ The early period of mining investments in Ghana coincided with a period of financial expansion led by The City and the shift in the political economy of Britain itself as British domestic manufacturing was experiencing a decline (Cain and Hopkins 1987:3, Hauner et al. 2017, Styve 2019). For the Bank of

\footnotetext{
${ }^{7}$ British accumulation of foreign assets across the Empire reached a high peak in the early 1890 s, reaching almost 170 per cent of GDP (Hauner et al. 2017).

${ }^{8}$ While mining had been undertaken by local entrepreneurs for centuries (Dumett 1998), the 1870s involved a "gold rush" among Europeans, starting in 1877.
} 
England, the new gold coming from the colonies buttressed confidence in the Sterling and in the Bank's ability to maintain payments without the gold standard breaking down (Van-Helten 1982: 536).

The Ashanti Goldfields Corporation (AGC) was Ghana's single largest gold producer, producing just over $50 \%$ of the gross revenue of all gold mines in Ghana between 1912 and 1993 (Taylor 2006). AGC's management in London carried weight at the colonial office (Stockwell 1995, Decker 2018) and the company played an important role in the context of British imperial expansion (McCaskie 1978, Wilks 1975, Taylor 2006). There was a strong degree of cohesion between the colonial office and AGC in the early history of the business (Taylor 2006) and, AGC benefited greatly from the railways and harbours the British colonial office provided (Dumett 1998). In return, the 1897 Agreement stipulated that 5\% of gross royalty should be paid by AGC to the colonial government (Taylor 2006). By virtue of its export earnings based primarily on gold and cocoa, Ghana was one of the most valuable colonial Sterling area members (Stockwell 1998). By independence, Ghana had also become a major cocoa producer, supplying around a third of the world market (Teal 1986). This is in line with Hilferding's (1910) argument that capital exports seek regions capable of satisfying a demand for raw materials in the host country -, and this structure largely remains today (Haag 2011).

While access to Ghana's raw materials was beneficial for imperial businesses and for the colonial administration, Hymer (1969) argues that the goal of the colonial administration was not economic growth and promotion of British business per se, but to maintain a certain outward-oriented political and economic structure. This led to the highly undesirable economic structure characterised by a heavy orientation towards raw material exports (Harris 1975, Huillery 2014, Taylor 2015, Austin et al. 2015) and an underdeveloped Ghanaian business sector (Butler 1997, Hymer 1969). While expatriate firms in Ghana were collusive, domestic African firms generally found themselves in highly competitive environments (Austin and Uche 2007). Furthermore, under colonialism, minimal funds were devoted to developing productivity in the manufacturing sector (Huillery 2014).

The establishment of the West African Currency Board (WACB) in 1912 is what lay the foundation for the colonial monetary and banking system in British West Africa (Hopkins 1970; Narsey 2016). This arrangement was effectively an extension of the imperial power of Britain, with the colonial currency distinct, backed by its own reserves, but held at parity and readily convertible to Sterling (Stockwell 1998; Narsey 2016). The Currency Board eliminated the risk of inflation in the colonies because of the strict control of currency issuance. That monetary tightness made it difficult to expand internal exchange, as additional domestic trade could only be financed when the balance of payments was favorable (and thus Sterling available). However the official reasons advanced to justify the creation of the WACB hide the real ones.

According to Narsey (2016: 153-158), British imperial authorities wanted to circulate a localised currency in West Africa which could not be used in international payments - and would therefore discourage trade (and possible foreign exchange leakages) of its African colonies beyond the sterling area. Most fundamentally, the WACB was an instrument helping Britain accumulate in London the foreign reserves of its members and thus attenuate the frequent liquidity crises of the London Money Market. Britain's "general imperial policy of extracting all available savings from colonies," according to Narsey (2016: 
210), "forced colonial governments' surplus balances and savings banks funds to London." As a result, Britain's position of major capital exporter under the international gold standard, and in a context of relative decline of its industrial base, depended on its control of the gold and foreign reserves of its colonies (Narsey 2016: 153-158). This financial supporting role of the WACB would take more significance after WWII. The accumulated sterling balances helped Britain deal with its balance of payments deficits. Krozewski (2001:47) describes as a 'myth' the assumption that Britain was a net exporter of long term capital to its colonies. Over the period 1948-53, she notes that "accumulated capital flows to West Africa (generously estimated) amounted to only about 14 percent of its sterling balances, roughly one quarter of the area's accumulated dollar surplus, and just outweighed the value of its gold exports" (Ibid: 49).

In this restrictive imperial setting, the main function of the domestic banking system, then, was to ensure that the monetary system worked smoothly and to settle the accounts of the colonial economy, rather than to increase the volume of money or finance structural change domestically (Hopkins 1970, Mkandawire 1999). In other words, it ensured a divorce between the financial system and domestic production.

Before the arrival of the Colonial Bank, to become Barclays Dominion Colonial and Overseas (DCO) later on, the Bank of British West Africa (BBWA) exercised a virtual monopoly over banking in Ghana, especially as Ghanaians were prohibited to create banks since 1906 (Austin and Uche 2007: 4; 17; Stockwell 1998). The two British banks colluded to avoid competing with each other and to exclude other banks. This cartel arrangement allowed them to rely more on fees than interest income to make profits. Because of this arrangement, both banks were not eager to take an active role in lending to domestic businesses - and were thus criticised for transacting primarily with expatriate companies, as well as for charging excessive fees and interest rates (Hopkins 1970, Stockwell 1998, Austin and Uche 2007, Rönnbäck and Broberg 2019). It was almost impossible for Ghanaians to access credit through impersonal, banking channels. As the World Bank's International Bank for Reconstruction and Development (IBRD) put it in 1954, the two British banks "have played virtually no part in developing local African entrepreneurship." (cited in Austin and Uche 2007: 25). However, as Cowen and Shenton (1991) demonstrate, British banks could not have lent to Africans even if they wanted to because of the customary forms of land tenure enshrined in colonial law. These laws prevented British banks from extending lending facilities to West African smallholders as the law was explicitly hostile to the recognition of African private property in land. As in Senegal, colonial firms in Ghana had very close links to the banks. For example, the BBWA was initially owned by the Elder Dempster shipping line.

Opposition to the financial structures of colonialism constituted a significant element to Ghana's nationalist struggle from the outset. ${ }^{9}$ During the decolonisation process, British policy was to seek to preserve the existing financial ties between Britain and the Gold Coast, partly to preserve the role of Sterling in financing international trade and investment and partly to maintain the earning power of the City of London (Fieldhouse 1986, Stockwell 1998, Krozewski 2001, Palan 2015, Cain and Hopkins

\footnotetext{
${ }^{9}$ Constraints related to being a member of the Sterling area included earnings being pooled in London (for which the colonies received an allocation of Sterling) and ceilings being placed on purchases by Sterling-area members from the Dollar area. The colony's inability to gain access to all the Dollars it contributed to the Sterling-area were especially resented by African politicians (Stockwell 1998:102-103).
} 
2016). Therefore, the British government and the Bank of England cooperated with Nkrumah's government to keep the Commonwealth "Sterling-minded" (Darwin 1988, Stockwell 1998, Goldsworthy 2008).

Nonetheless, in 1961, exchange controls in Ghana ended free convertibility of the new currency with Sterling, which means that in principle, Ghana obtained an additional degree of freedom in its choice of policy instruments compared with Senegal - as it could devalue its currency and finance itself through central bank credit (Teal 1986, Stockwell 1998). As in Senegal, there was a shift in ownership in the banking sector post-independence. In the 1960s and 1970s, large parts of Ghana's banking system was relocated to the public sector (Hutchful 2002). State owned banks included the largest commercial bank as well as a number of secondary and development banks, and non-bank financial institutions in insurance and social security.

At independence in 1957, the majority of foreign firms were British, but their direct influence on policy was modest (Decker 2008, 2011). ${ }^{10}$ Their influence was weakened in the 1970s, but they remained fairly embedded in the business environment. ${ }^{11}$ Inspired by radical structuralist theories that highlight the importance of actively stimulating structural transformation to achieve industrialisation (e.g Amin 1974, Prebisch 1950), the postcolonial state of the 60s and 70s embarked on expansionary schemes, including various forms of controls on finance and production to shape the structure of the economy (Hutchful 2002). Nkrumah's policies of indigenisation reserved certain small business sectors to Ghanaian capital and gave the state majority shares in major foreign banks, insurance companies, and timber firms (Kraus 2002). He was suspicious of both foreign and domestic corporate influence, but he accepted that foreign investment was required to achieve his ambitious development plans (Decker 2011). Similar to the Senegalese case, even though the Nkrumah regime allegedly opted for a socialist path, it was incapable of transcending the existing institutions and practices (Murray 1967, Fitch and Oppenheimer 1966).

\section{Liberalization since the 1980s - Cementing the Divorce between Finance and Production}

As for Senegal, the 1980s marked a clear structural break for Ghana, as the SAPs forced the Ghanaian government to re-emphasise the private sector, adopt export-led growth strategies, liberalise trade and currency regimes, and shrink the state's economic roles (Kraus 2002). External pressure for economic liberalisation meant that Ghana needed to open its economy to foreign capital and multinationals to a greater extent again and to ease investment rules. In the 1990s, the World Bank and aid donors pushed the Ghanaian government to conduct dialogues with the private sector as a condition for aid, and the World Bank even organised an investment meeting in Ghana for foreign capital (Kraus 2002). Furthermore, under the SAPs, the Ghanaian government eliminated the indigenisation decrees that had reserved whole economic sectors to local businesses or the state. The liberalisation of credit and interest rates documented in the next section also led to the flow of credit away from certain productive sectors (especially

\footnotetext{
${ }^{10}$ There had been some diversification of dependency already at the end of the colonial period, as Britain's share of Ghana's trade fell from 62.8\% to 39.7\% between 1939 and 1957 (Stockwell 1995: 278).

${ }^{11}$ This is in line with Nkrumah's (1965) observation that independence did not put an end to dependence, but rather changed the rules of the game (see also White 2017).
} 
agriculture) and into areas such as commerce (Tsikata and Amuzu 1993, Hutchful 2002). See figure 2 for the impact on value added in agriculture.

Compared to the decade preceding adjustment, the Ghanaian economy made major gains in terms of increasing export earnings (Hutchful 2002). However, the gains in growth were mostly based on an intensification of primary commodity exports, rather than addressing issues of low productivity, low value-added, and supply constraints in the economy. For example, while there was an increase in foreign investment during the economic recovery program starting in 1983, the mining sector, and gold in particular, received virtually all the significant foreign investment. There is a measure of continuity in global mining finance and extraction, as the UK Minister of State in the Department of International Trade stated in 2016, "the world quite simply is mined from the UK and that is not going to change." (quoted in Styve 2019: 83). Beyond gains in growth due to an increase in primary commodity exports, the structural change that took place was regressive: When it came to the domestic economic performance, some sectors, such as manufacturing and the small enterprise sectors, actually did worse in the wake of the reforms (Hutchful 2002). The Ghanaian economy was thereby returning to its colonial structure.

Notably, it was the financial services and communications sectors that grew the most in the adjustment period of the 1980s and 1990s (Hutchful 2002). The worst performance was in agriculture which barely grew at $2 \%$ per year, with growth in several years being negative. Figure 2 demonstrates the increase in value added for the agricultural sectors during the post-independence era, and the steady fall since the SAPs were first implemented in the 1980s. ${ }^{12}$ Manufacturing value added has remained consistently low since independence.

Figure 2: Value added as \% of GDP for the manufacturing and agricultural sectors in Ghana

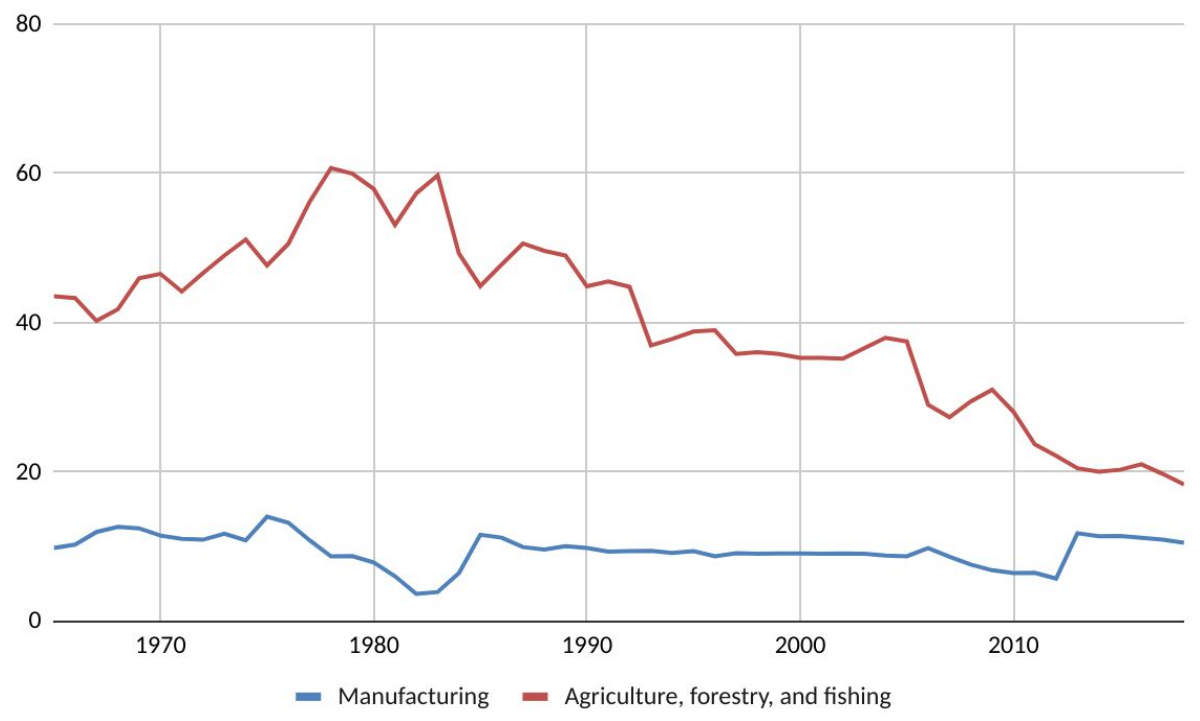

Source: World Bank World Development Indicators

\footnotetext{
${ }^{12}$ Value added is measured as the net output of a sector after adding up all outputs and subtracting intermediate inputs.
} 
Independence also gave somewhat of a new direction to the banking sector, as the establishment of Ghana's first domestic bank in 1953 led to increased competition for the British banks (Stockwell 1995, 1998). As banking monopolies were broken up after independence, domestic credit became more easily available to the domestic private sector: Domestic credit provided by the financial sector as a percentage of GDP rose from 10\% in 1961 to 32\% in 1967 (see Figure 3). It remained on average above 30\% until 1979, when it crashed before recovering again in the 2000s. In 2018, domestic credit provided by the financial sector was $26 \%$ of GDP. A similar cyclical pattern can be observed in domestic credit to the private sector as a percentage of GDP, rising in the 1960s, dipping in the 1980s, and then rising again in the 2000s. Due to this cyclicality, the differences between 1960 and 2018 are modest.

Figure 3: Cyclicality in Financial Sector Indicators for Ghana

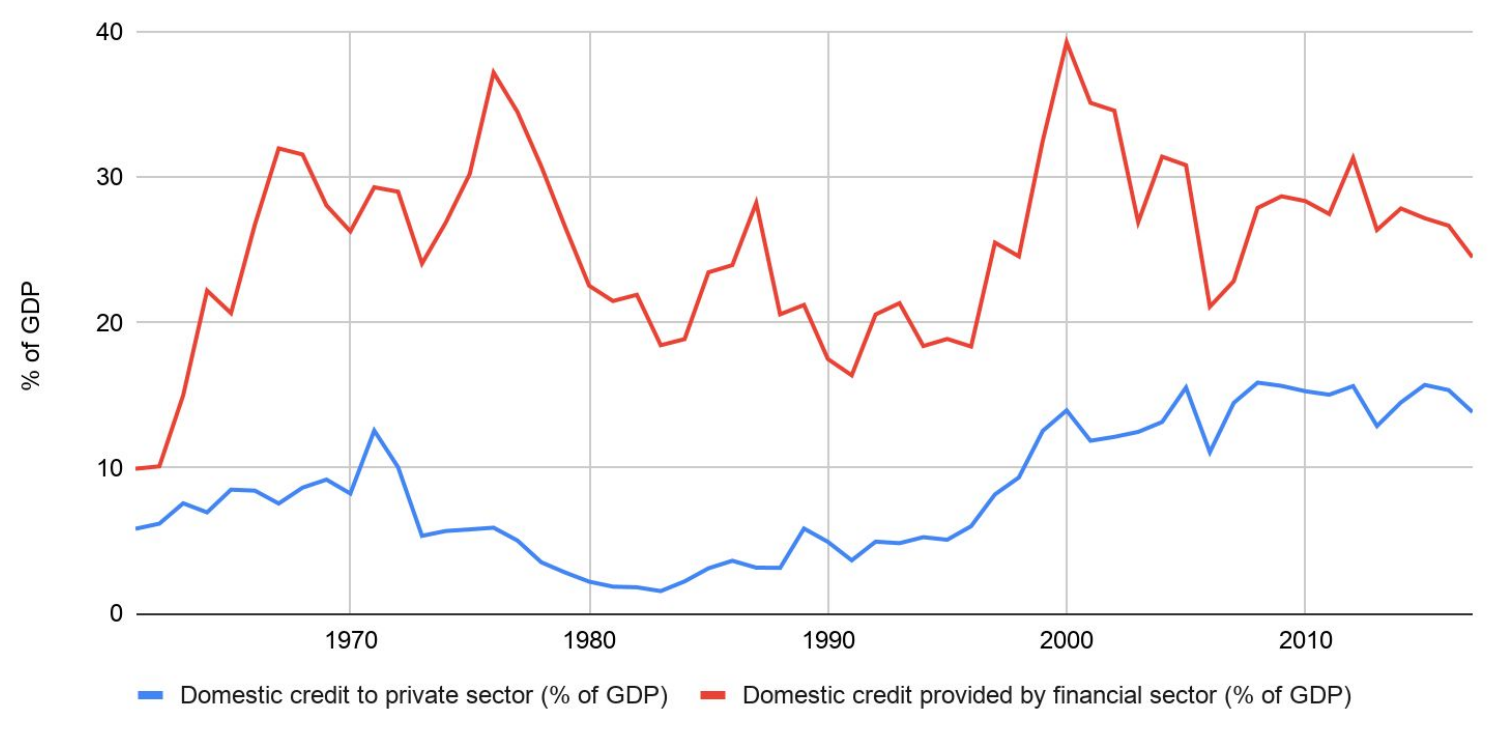

Sources: The World Bank's Global Financial Development Database, World Development Indicators

Although there had been a shift in ownership post-independence towards the public sector, the period of structural adjustment that started in 1983 reoriented the Ghanaian economy towards global capital again (Hutchful 2002). These reforms were carried out in close collaboration with the World Bank and IMF, with a relatively high presence of foreign banks (Jones 2020). As a part of the SAPs, the Bank of Ghana focused on increasing foreign reserves and decreasing inflation to low single digits through imposing strict credit ceilings to contain excess demand and imports (Kraus 2002, Epstein and Heintz 2006). After 1988, all sectoral credit ceilings, including the mandatory $20 \%$ lending to agriculture, were removed and preferential interest rates to priority economic sectors, such as agriculture, manufacturing and exports, were abolished (Hutchful 2002). ${ }^{13}$

\footnotetext{
${ }^{13}$ In addition, beginning in 1983, a series of reforms were introduced to liberalise foreign exchange markets and to make the exchange rate increasingly market determined (Epstein and Heintz 2006).
} 
The SAP packages, incidentally, had a similar effect to the colonial currency boards, and the result was that existing credit became insufficient for private sector needs, interest rates were high, and the recapitalised banks were not able to support the economy's productive sectors (Kraus, 2002, Hutchful 2002). Financial depth in Ghana (measured by the ratio of money supply to GDP) fell following the reforms. Since the 2000s, the banking sector has grown rapidly (Jones 2020). There was a second wave of SAP reforms in the early 2000s, which included the introduction of universal banking, allowing easier access for banks to engage in commercial, development, merchant, and investment banking (Quartey 2005), and which paved the way for the establishment of an inflation targeting regime that was formally established in 2007 (Bleaney et al. 2020). The reforms led to a fall in the share of government controlled banks (asset share declined from 29\% to 17\%, 1990-2017) and a rise in the share of domestically privately controlled banks (from $18 \%$ to $32 \%$ of total bank assets, 1990-2017) (Jones 2020). While foreign ownership of banks has decreased since colonialism, the degree of concentration remains high (Epstein and Heintz 2006, Jones 2020). Table 1 at the beginning of this section demonstrates the high presence of foreign banks in total banks as well as foreign bank assets among total. To provide some comparison, the amount of foreign banks in Ghana is drastically higher than Germany and slightly higher than the UK - one of the world's financial centers. In terms of assets held by foreign banks, the proportion in Ghana is over 50 percentage points higher than both the figure for the UK and Germany. Moreover, as with Senegal, bank loans remain largely short-term and are characterised by high both interest rates and high profits, as during the colonial period (Epstein and Heintz 2006, Adjei-Frimpong et al. 2016, Jones 2020).

Similarly to Senegal, the data on deposit banks' claims on domestic non-financial sector to GDP - a measure of productive lending to GDP - demonstrates continuity at very low levels compared to the UK and Germany. There was an improvement for Ghana in the 1960s, when the government was enacting reforms to direct finance towards the agricultural sector, but that became undone with liberalization. However, in the 2000s, it has again reached the levels of the 1960s (still very low compared to Germany and the UK).

Today, Ghana remains an important supplier of raw materials to the world as well as a market for manufactured goods and capital (Haag 2011). For example, in 2018, 49\% of Ghana's exports consisted of gold, 23\% crude petroleum and 9\% cocoa beans (The Observatory of Economic Complexity 2018). However, the United Kingdom is no longer the main export destination. ${ }^{14}$ Notably, the United Kingdom has a larger presence as an exporter to Ghana, as it is a key source of Ghana's imports (mostly manufacturing goods and refined goods) after China, the US, the Netherlands and India.

AGC can in many ways be viewed as a representative of changes in production from the colonial period to contemporary times. It has evolved from a nineteenth century stand-alone British investment in the pre-colonial Ashanti kingdom to a twenty-first century African multinational, as it was taken over by the South African gold producer, Anglogold, creating a new company, Anglogold Ashanti, in 2004. While AGC has pursued a gold hedging program from the 1990s, and started investing in other financial

14 The main export destinations are India, Switzerland, China, South Africa and the United Arab Emirates. 
instruments, its investments in global financial markets is disconnected from its extraction in the Ghanaian mining sector (Taylor 2006).

Ghana has entered another agreement with the IMF after the end of the most recent commodity boom (e.g. IMF 2018). The policy conditionalities of this round are in line with the Wall Street Consensus, which involves reimagining development interventions as opportunities for global finance through policies such as creating local currency capital markets (Gabor 2019). With this, the Ghanaian government has been focusing on ensuring financial stability and improving the reputation of the Ghanaian banking sector among international investors, rather than focusing on increasing bank lending to the productive economy (Jones 2020: 167). Strikingly, Jones (2020) finds that the effects of the reforms include banks reducing the volume of lending to the real economy and increasing holdings of government securities. Thus, the divorce between finance and investments in the real economy has not only endured, but deepended with the Wall Street Consensus.

Furthermore, while the colonial period involved direct financial and economic repression, inflation targeting in the contemporary era plays a similar role. This is evident as policies to develop the money and financial markets in Ghana are ultimately pursued in order to make inflation targeting more effective (Epstein 2019), and these policies are pushed actively by international institutions and donors (Gabor 2019).

While the Wall Street Consensus promotes the development of new financial instruments, the logic of the interventions - in terms of promoting an extraversion of the financial system rather than orienting it towards the stimulation of domestic production - is similar in logic to how the financial system was shaped by the British Empire at the turn of the last century. While the extraversion that took place during the colonial period was forced and to the benefit of British trade and the City, the extraversion today is to the benefit of global corporations and finance more generally - and notably also the City. ${ }^{15}$

\section{Conclusion}

One of the central premises of important parts of the financialisation literature is that we have been living in a new era of capitalism, characterised by a historical shift in the finance-production nexus. Finance has begun to behave abnormally towards production. It has assumed a disproportionate economic size and, more importantly, has divorced from 'real' economic pursuits. Such claims, to our view, do not only suffer from a lack of longue durée perspective, but they also betray a disinterest in how the financial aspects of imperialism have been operating in the former European colonies during the last 150 years. In this paper, we have tried to challenge this 'divorce' view by studying the longue durée of colonial and post-independence finance in Senegal and Ghana. We show how the deployment of finance in both

\footnotetext{
${ }^{15}$ London remains the largest financial centre, followed by New York, when measured in terms of international lending and deposits (Cain and Hopkins 2016). This has led Palan (2015) to dub the financial center in the UK today "a second British Empire".
} 
countries was and continues to be divorced from developing successful productive systems, as it was and continues to be oriented towards foreign profits.

Both the cases of Senegal and Ghana demonstrate the remarkable continuation of foreign-dominated banking sectors and their lack of orientation towards financing domestic productive structures. This situation has made it difficult to achieve autonomous growth (Green 1971, Amin 1973, Howard 1978). Another key finding that emerges from both case studies is that even if foreign finance and its agents do not currently directly dominate as in the colonial period, they still control the orientation of the latter's economic development, through policy conditionality, norm-setting, and investment decisions.

Furthermore, the colonial banking sectors played key roles in suppressing domestic business, which is a structure that the Wall Street Consensus marks a continuation of. There was an important period of disruption in the post-independence era of the 1960s and 1970s, where the financial systems were briefly oriented to a larger extent towards domestic production, but this development was cut short by the liberalization and deregulation that has been taking place since the 1980s in both countries. Thus, while the 'expansion' of financial instruments, infrastructures and marketplaces take place, they rather reinforce the striking divorce pattern.

Thus, this longue duree perspective allows to see the contemporary period as a return to the high dominance of foreign banks during the colonial period in the case of Ghana - which had a period of a more domestically oriented banking system in the 1960s and 1970, and a continuation from the colonial period for Senegal. In short, finance continues to be oriented towards satisfying capital abroad (first colonial, now global), rather than domestic productive sectors. These developments therefore suggest, at best, a return to colonial economic logic but with slightly new forms and instruments. It is in that sense that we need to go 'beyond financialisation' to focus on the deployment and logics of finance as a central part of imperialism.

In the case of Senegal, these continuities are also particularly striking in terms of the monetary framework, which remains colonial as the former colonizer continues to impact the organisation of the Senegalese monetary and banking system.

Given these findings, the divorce between the financial and the 'productive' economy cannot be considered a new empirical phenomenon of the last decades. The slight expansion and diversification of financial actors and instruments, as byproducts of the implementation of the IMF and World Bank's structural adjustment plans and the so-called Wall Street Consensus, has done little to change the enduring divorce between finance and domestic-oriented production in both Senegal and Ghana. The changes associated with the 'expansion' meaning of financialisation have been mostly quantitative, as they have not altered the overall structure of divorce and extraversion.

What does this mean for the debate on 'financialization in developing and emerging economies'?

First, only core economies, those having escaped the most vicious distortions brought by imperialism, can imagine that the normal operation of finance under capitalism is to support production. Instead, as this paper suggests, what we have been witnessing during the last decades is that globalised finance is 
somehow structurally behaving, mutatis mutandis, in some parts of the developed world as it used to in the periphery - neglecting the domestic economy's financial needs. In this sense, economies in the Global North can learn from the experiences of the Global South.

Second, the structural disadvantages of the Global South are even more pronounced and have a longer history than a focus on recent decades and narrow financial issues can reveal. While the orientation of the economic and financial systems towards global capital rather than domestic production dates back to the working of foreign capital through foreign banks, the colonial administration, and multinational corporations such as CFAO and AGC during colonial times, this orientation has continued in recent years, encouraged by the same corporations, official aid, and capital with conditionalities provided by the IMF and the World Bank.

\section{References}

Abeles, M., E. P. Caldentey and S. Valdecantos. 2018. Studies on financialisation in Latin America. Santiago, Chile: Economic Commission for Latin America and the Caribbean.

Adjei-Frimpong, K., C. Gan, B. Hu. 2016. "Competition in the banking industry: Empirical evidence from Ghana." Journal of Banking Regulation 17, 159-75.

Austin, G. and C. U. Uche. 2007. "Collusion and Competition in Colonial Economies: Banking in British West Africa, 1916-1960.” The Business History Review 81(1): 1-26.

Alami I. 2019. Global Finance Capital and Third World Debt. In: Ness I., Cope Z. (eds) The Palgrave Encyclopedia of Imperialism and Anti-Imperialism. Palgrave Macmillan, Cham. https://doi.org/10.1007/978-3-319-91206-6_123-1

Alami, I. 2020. Money Power and Financial Capital in Emerging Markets: Facing the Liquidity Tsunami, Routledge.

Alibert, J. 1983. De la Vie Coloniale auf défi international: Banque de Sénégal, BAO, BIAO 130 ans de banque en Afrique, Chotards \& Associés, Paris.

Amaïzo, Y. E. 2001. Naissance d'une banque de la zone franc: 1848-1901. Priorité aux propriétaires d'esclaves, L'Harmattan, Paris.

Amin, S. 1973. Neo-Colonialism in West Africa. Monthly Review Press, New York and London.

Amin, S. 1974. Accumulation on a World Scale: A Critique of the Theory of Underdevelopment, vols. 1 and 2, (New York: Monthly Review Press.

Amin, S. 1976. Unequal Development: An Essay on the Social Formations of Peripheral Capitalism. New York: Monthly Review Press. 
Arrighi, G. 2002. The African Crisis, New Left Review

Arrighi, G. 2010. The Long Twentieth Century: Money, Power and the Origins of Our Time. London: Verso

Austin, G., E. Frankema and M. Jerven. 2015. Patterns of Manufacturing Growth in Sub-Saharan Africa: From Colonization to the Present. CGEH Working Paper Series 71.

Banaji, Jairus. 2016. "Merchant Capitalism, Peasant Households and Industrial Accumulation: Integration of a Model." Journal of Agrarian Change 16(3): 410-431.

BCEAO. 2012. Rapport sur l'évolution des conditions d'activité de banque dans l'UEMOA au cours des cinq dernières années (2007-2012), BCEAO, November.

BCEAO. 2019. Rapport Annuel 2018, Commission bancaire union monétaire ouest-africaine, https://www.bceao.int/fr/publications/rapport-annuel-de-la-commission-bancaire-2018

BCEAO. 2020a. Rapport sur les conditions d'activité de Banque dans l'UEMOA 2019, BCEAO, March.

BCEAO. 2020b. Rapport annuel 2019, BCEAO, June.

Bellito, M. 2001. Une histoire du Sénégal et de ses entreprises publiques. Paris: L’Harmattan.

Bernards, Nick. 2019. “'Latent' surplus populations and colonial histories of drought, groundnuts, and finance in Senegal." Geoforum https://doi.org/10.1016/j.geoforum.2019.10.007

Bernards, N. 2016. "The International Labour Organization and the ambivalent politics of financial inclusion in West Africa." New Political Economy 21(6):606:620.

Bichler, S. and J. Nitzan. 2012. "Imperialism and Financialism: A Story of a Nexus", Journal of Critical Globalization studies, Issue 5: 42-78.

Bleaney, M. \& Morozumi, A. \& Mumuni, Z. 2020. "Inflation Targeting and Monetary Policy in Ghana," Journal of African Economies, Centre for the Study of African Economies (CSAE), vol. 29(2), pages 121-145.

Bonin, Hubert. 1987. CFAO Cent ans de compétition, Paris: Economica.

Bonin, H., 2008. CFAO (1887-2007): la réinvention permanente de commerce outre-mer. Paris: Publications de la SFHOM.

Bonizzi, B., A. Kaltenbrunner and J. Powell. 2020. 'Subordinate Financialization in Emerging Capitalist Economies,' in P. Mader, D. Mertens and N. van der Zwan (eds), The International 
Handbook of Financialization. Routledge.

Boone, C. 2005. "Capital, and the Politics of Banking Reform in Sub-Saharan Africa", Comparative Politics, Vol. 37, No. 4: pp. 401-420

Boone, C., 1992. Merchant Capital and the Roots of State Power in Senegal 1930-1985. Cambridge, UK: Cambridge UniversityPress

Borón, Atilio A. 2005. Empire and Imperialism: A Critical Reading of Michael Hardt and Antonio Negri London and New York: Zed Books.

Boyce, J. and Ndikumana, L. 2011. Africa's Odious Debts: How Foreign Loans and Capital Flight Bled a Continent. London: Zed Books.

Braun. B. 2016. From Performativity to Political Economy: Index Investing, ETFs, and Asset Manager Capitalism, New Political Economy, 21(3), 257-273.

Butler, L. J. 1997. Industrialization and the British Colonial State: West Africa, 1939-1951. London: Frank Cass.

Cain, P.J., and A. G. Hopkins. 1987. "Gentlemanly Capitalism and British Expansion Overseas II: The New Imperialism, 1850-1945." The Economic History Review 40 (1): 1-26.

Christophers, B. and Fine. 2020. The value of financialization and the financialization of value, in Mader, Mertens and van der Zwan. International Handbook of Financialization. 2020, 19-30

Christophers, B. 2015. The limits to financialization. Dialogues in Human Geography, 5(2), 183-200. https://doi.org/10.1177/2043820615588153

Coquery-Vidrovitch, C. 1975. L'Impact des Interets: SCOA at CFAO dans l'Ouest Africain,1910-1965. J. African History 16 (4), 595-621.

Correa, E. and G. Vidal. 2012. "Financialization and Global Financial Crisis in Latin American Countries." Journal of Economic Issues (46): 541-548.

Cowen, M.P. and R.W. Shenton. 1991. "Bankers, peasants, and land in British West Africa 1905-37." The Journal of Peasant Studies 19(1): 26-58.

Cunha, A. M., D. M. Prates, J. d. S. Bichara. 2010. "The Brazilian economy: its new role in the international financial system.” América Latina Hoy (54): 167-197.

Darwin, J. 1988. Britain and Decolonisation: The Retreat from Empire in the Post-War World. New York: St. Martin's. 
Decker, S. 2008. "Building Up Goodwill: British Business, Development and Economic Nationalism in Ghana and Nigeria, 1945-1977” Enterprise \& Society 9(4): 602-613.

Decker, S. 2011. "Corporate political activity in less developed countries: The Volta River Project in Ghana, 1958-66”, Business History 53(7): 993-1017.

Decker, S. 2018. "Africanization in British Multinationals in Ghana and Nigeria, 1945-1970" Business History Review 92(4): 691-718.

Déniz, J. and W. C. Marshall. 2018. "Latin American Structuralism and Current Financialization." International Journal of Political Economy (47): 48-68.

Desai. R. 2019. What is to be done? The importance of Samir Amin's answer, Globalizations, 16:7, 1053-1061, DOI: $\underline{10.1080 / 14747731.2019 .1654286}$

Dieng, A.A. 1982. Le Rôle du système bancaire dans la mise en valeur de l'Afrique de l'Ouest. Dakar : Les Nouvelles Éditions Africaines

Diouf, M. 2002. L'Endettement puis l'ajustement. L'Afrique des Institutions de Bretton Woods, L'Harmattan.

Doumbia, S. 2011. "Surliquidité bancaire et sous-financement de l'économie: Une analyse du paradoxe de l'UEMOA." Revue Tiers Monde 205: 151-70.

dos Santos, T. 1972. Dependencia y Cambio Social. Santiago de Chile: CESO

Dresch, J. 1946. «Sur une géographie des investissements de capitaux. L'exemple de l'Afrique Noire », Bulletin de l'Association de géographes français, $\mathrm{N}^{\circ} 177-178$, March-April: pp. 59-64

Dumett, R. E. 1998. El Dorado in West Africa: The Gold Mining Frontier, African Labor, and Colonial Capitalism in Gold Coast, 1875-1900, Ohio University Press

Durand, Cedric and William Milberg. 2020. 'Intellectual monopoly in global value chains.' Review of International Political Economy 27(2): 404-429.

Enoch C., P. Mathieu and M. Mecagni. 2015. "Pan-African Banks : Opportunities and challenges for cross-border oversight”, Washington, D.C. : IMF.

Epstein, G. 2005. Financialization and the World Economy. Cheltenham (UK): Edward Elgar.

Epstein, G. 2019. "Financialization, rentier interests and central bank policy", in G. Epstein. ed. The Political Economy of Central Banking - Contested Control and the Power of Finance. Elgar Publishing. 
Epstein, G., and J. Heintz. 2006. Monetary Policy and Financial Sector Reform For Employment Creation and Poverty Reduction in Ghana. PERI Working Paper No. 113

Fasianos et. al. 2016. Have We Been Here Before? Phases of Financialization within the 20th Century in the United States. Levy Economics Institute, Working Papers Series No. 869, Available at SSRN: https://ssrn.com/abstract $=2801088$ or http://dx.doi.org/10.2139/ssrn.2801088

Fieldhouse, D.K. 1986. Black Africa 1945-1980: Economic Decolonization and Arrested Development. London.

Fitch, B. and M. Oppenheimer. 1966. Ghana: End of An Illusion, Monthly Review Press.

Foster, J. B. 2010. “The Age of Monopoly-Finance Capital,” Monthly Review 61(9).

Foster, John Bellamy. 2019. "Late Imperialism Fifty Years After Harry Magdoff's The Age of Imperialism." Monthly Review 71(3). Available at: https://monthlyreview.org/2019/07/01/late-imperialism/

Founou-Tchuigoua, Bernard. 1981. Fondements de l'Economie de Traite au Sénégal. Paris: Silex Editions

Frankel, S.H. 1938. Capital investment in Africa: its course and effects, African Research Survey, Oxford University, Press.

Furtado, C. 1970. Economic Development of Latin America. London: Cambridge University Press

Gabor, D. 2018. 'Goodbye (Chinese) Shadow Banking, Hello Market-based Finance,' Development and Change 49(2):394-419.

Gabor, D. 2019. Securitization for Sustainability: Does it help achieve the Sustainable Development Goals? Washington, D.C.: Heinrich Böll Stiftung.

Gabor, D. 2020. "The Wall Street Consensus." SocArXiv. July 2. doi:10.31235/osf.io/wab8m. https://osf.io/preprints/socarxiv/wab8m/

Gellar, Sheldon. 1995. Senegal: An African Nation Between Islam And The West. Abingdon: Routledge

Goldsworthy, D. 2008. "Keeping change within bounds: Aspects of colonial policy during the Churchill and Eden governments, 1951-57", The Journal of Imperial and Commonwealth History 18(1): 81-108.

Green, R. H. 1971. "Reflections on economic strategy, structure, implementation and necessity: Ghana and the Ivory Coast, 1957-67", in P. Foster and A.R.Zolberg (eds), Ghana and the Ivory Coast Perspectives on Modernisation. Chicago, US: University of Chicago Press. 
Guillaumont, P. and S. Guillaumont. 1972. «Zone franc et développement : les caractéristiques de la zone franc sont-elles dissociables ? », in R. Tremblay (ed), Africa and Monetary Integration, HRW editions, Montreal and Toronto : pp. 289-350.

Haag, Diana. 2011. "Mechanisms of Neo-colonialism Current French and British influence in Cameroon and Ghana”, ICIP WORKING PAPERS 2011/6. Institut Català Internacional per la Pau Barcelona

Harris, D. 1975. The Political Economy of Africa: Underdevelopment or Revolution. In D. Harris, ed. The Political Economy of Africa. New York: Schenkman, 1-47.

Hutchful, Eboe. 2002. Ghana's Adjustment Experience: The Paradox of Reform. Geneva: UNRISD

Hauner, T., B. Milanovic, and S. Naiduz. 2017. "Inequality, Foreign Investment, and Imperialism." Accessed 22.07.2018. https://mpra.ub.uni-muenchen.de/83068/.

Hilferding, R. 1981. Finance Capital: A Study of the Latest Phase of Capitalist Development. London: Routledge \& Kegan Paul.

Hobson. J.A. 1902. Imperialism. New York: Cosimo.

Hopkins, A. G. 1970. "The Creation of a Colonial Monetary System: The Origins of the West African Currency Board.” African Historical Studies 3(1): 101-132.

Hopkins. 2020. Economic History of West Africa, London: Routledge. 2nd. Ed.

Howard, R.S. 1978. Capitalism and Underdevelopment in Ghana. Croom Helm.

Hudson, M. 2003. Super Imperialism. The Origin and Fundamentals of U.S. World Dominance, Second Edition, Pluto Press.

Hudson, P. J. 2017. Bankers and Empire: How Wall Street Colonized the Caribbean. University of Chicago Press.

Huillery, E. 2014. "The Black Man's Burden: The Cost of Colonization of French West Africa", The Journal of Economic History, vol.74 n¹: 1-38.

Hymer, S. 1969. The Political Economy of the Gold Coast and Ghana, Center Discussion Paper, No. 73, Yale University, Economic Growth Center, New Haven, CT

Imam, P., A and C. Kolerus. 2013. West African Economic and Monetary Union Financial Depth and Macrostability, IMF report 6/13

IMF. 2018. 'Ghana : Fifth and Sixth Reviews Under the Extended Credit Facility, Request for Waivers for Nonobservance of Performance Criteria, and Request for Modification of Performance Criteria-Press 
Release; Staff Report; and Statement by the Executive Director for Ghana'. Country Report 18/113 https://www.imf.org/en/Publications/CR/Issues/2018/05/02/Ghana-Fifth-and-Sixth-Reviews-Under-the-E xtended-Credit-Facility-Request-for-Waivers-for-45841

Jones, E. 2020. “Ghana: Reformist Politicians Drive Basel Implementation.” in Emily Jones (Ed.) The Political Economy of Bank Regulation in Developing Countries. Oxford: Oxford University Press

Kaltenbrunner, A. and Painceira, J. P. 2018. Subordinated Financial Integration and Financialisation in Emerging Capitalist Economies: The Brazilian Experience, New Political Economy, 23:3, 290-313, DOI: $\underline{10.1080 / 13563467.2017 .1349089}$

Kar, D., S. Freitas, J. M. Moyo, G. S. Ndiaye. 2013. Illicit Financial Flows and the Problem of Net Resource Transfers from Africa: 1980-2009. Global Financial Integrity.

Karwowski, Ewa and Engelbert Stockhammer. 2016. 'Financialisation in emerging economies: a systematic overview and comparison with Anglo-Saxon economies' Journal Economic and Political Studies 5(1): 60-86

Ki Zerbo, J. 1957 "L'économie de traite en Afrique Noire ou le pillage organisé (xve-xxe siècle) », Présence Africaine, New Serie, ${ }^{\circ}$ 11: 7-31.

Koddenbrock, K and Ndongo Sylla 2019 Towards a political economy of monetary dependency: The case of the Franc CFA, MaxPo Discussion Paper, Paris.

Kraus, J. 2002. "Capital, power and business associations in the African political economy: A tale of two countries, Ghana and Nigeria” Journal of Modern African Studies 40(3): 395-436.

Kregel, J. A. 2004. "Can we create a stable international financial environment that ensures net resource transfers to developing countries?", Journal of Post Keynesian Economics, 26:4, 573-590

Kregel, J. A. 2006. “Employment of Last Resort as an Alternative Development Strategy”, The Levy Economics Institute, Bard College.

Krippner, G. 2005. The financialization of the American economy, Socio-Economic Review, Volume 3, Issue 2, May 2005, Pages 173-208, https://doi.org/10.1093/SER/mwi008

Kvangraven, I.H. 2020. 'Beyond the Stereotype: Restating the Relevance of the Dependency Research Programme', Development and Change June 4th.

Krozewski, G. 2001. Money and the End of Empire. British International Economic Policy and the Colonies, 1947-1958, New York, Palgrave Macmillan.

Lapavitsas, C. 2013. Profiting without producing. How Finance exploit us all, Verso, London and New York. 
Laskaridis, C., and J. Toporowski. 2016. "Financial Sector Development in the Context of the Franc Zone.” Working Paper Series 158, FESSUD, Leeds University Business School.

Lelart M. 1998. L'origine du compte d'opérations, dans La France et l'outre-mer, un siècle de relations monétaires et financières, Colloque tenu à Bercy, les 13,14, 15 novembre 1996, Comité pour l'histoire économique et financière de la France, Paris, pp.529-545.

Levy-Orlik, N. and E. Ortiz. 2016. The Financialization Response to Economic Disequilibria: European and Latin American Experiences. Edward Elgar Publishing: Cheltenham UK.

Lydon, G. 1997. Les péripéties d'une institution financière : la Banque du Sénégal, 1844-1901. Michigan State University

Mader, P., Mertens, D. and Natasha van der Zwan. 2020. The Routledge Handbook on Financialization. London: Routledge

Magnan-Marionnet, F. 2016. "Les émissions de titres de dette souveraine en zone Franc : évolutions, enjeux et principaux défis en UEMOA et dans la CEMAC", Techniques Financières et Développement, vol. 123 , no. 2 , pp. 39-50.

Marx, K. 1867. Capital Volume One. New York: Random House

McCaskie, T. C. 1978. "The creation of Ashanti Goldfields Corporation, Ltd., ca. 1890- 1910: An episode in the colonial impact upon Asante", Asantesem 9: 37-55.

McKinnon, R. I. 1973. Money and Capital in Economic Development. Washington, DC: Brookings Institution.

Mecagni, M., D. Marchettini and R. Maino. 2015. "Evolving Banking Trends in Sub-Saharan Africa. Key features and challenges", IMF, Africa Department.

Milberg, William. 2009. 'Shifting sources and uses of profits: sustaining US financialization with global value chains' Economic and Society 37(3):420-451.

Mkandawire, T. 1999. "The Political Economy of Financial Reform in Africa”, Journal of International Development 11: 321-342

Moitt, B. 1989. Slavery and Emancipation in Senegal's Peanut Basin: The Nineteenth and Twentieth Centuries. The International Journal of African Historical Studies, 22(1), 27-50.

Murray, R. 1967. "Second Thoughts on Ghana”, New Left Review 1(42);25-39. 
Naoroji, D. 1902. Poverty and Un-British Rule in India. Publications Division, Ministry of Information and Broadcasting, Government of India.

Narsey, W. 2016. British Imperialism and the Making of Colonial Currency Systems, Palgrave MacMillan.

Nkrumah, K. 1965. Neocolonialism. The last Stage of Imperialism, Thomas Nelson \& Sons, Ltd., London.

Palan, R. 2015. "The Second British Empire and the Re-Emergence of Global Finance." In Legacies of Empire: The Imperial Roots of the Contemporary Global Order, edited by S. Halperin and R. Palan, 50-68. Cambridge: Cambridge University Press.

Painceira, J.P. 2012. "Developing Countries in the Era of Financialisation: From Deficit-Accumulation to Reserve-Accumulation”, in C. Lapavitsas, ed. Financialisation in Crisis, Leiden: Brill: 195-215.

Parmentier, J.M. and R. Tenconi. 1996. Zone franc en Afrique. Fin d'une ère ou renaissance ?, L'Harmattan, Paris.

Patnaik, P. 2001. "Imperialism and the Diffusion of Development", Social Scientist, Vol. 29, No. 3/4 (Mar. - Apr., 2001), pp. 3-18

Patnaik, P. 2018. "Reflections on contemporary imperialism", in S. Sen and C. Marcuzzo. eds. The Changing face of Imperialism. From Colonialism to Contemporary Capitalism, New York: Routledge, pp.61-77

Patnaik, U. 2017. "Mr Keynes and the forgotten holocaust in Bengal, 1943-44: Or, the macroeconomics of extreme demand compression", Studies in People's History, 4, 2: 1-14

Patnaik, U. and P. Patnaik. 2016. A Theory of Imperialism, Columbia University Press.

Pigeaud, F., and N. S. Sylla. 2018. L'arme invisible de la Françafrique: Une histoire du franc CFA. Paris: La Découverte

Pouemi, J. T. 1980. [2000]. Monnaie, servitude et liberté: La répression monétaire de l'Afrique. Paris: Menaibuc.

Powell, J. 2013. "Subordinate Financialization: A Study of Mexico and Its NonFinancial Corporations." $\mathrm{PhD}$ dissertation, SOAS, University of London.

Prebisch, R. 1939. 'El Ciclo Económico y la Politica Monetaria' ['The Economie Cycle and Monetary Policy'], in E. Garcia Vasquez (ed.) Obras de Raul Prebisch, Vol. 2 [The Works of Raul Prebisch, Vol. 2], pp. 647-57. Buenos Aires: Fundación Raul Prebisch. 
Prebisch, R. 1950. The Economic Development of Latin America and its Principal Problems. New York: United Nations.

Quartey, P. 2005. "Financial sector development, savings mobilization and poverty reduction in Ghana." World Institute for Development Economics Research 32.

Ranis, M. 1994. "Senegal: stabilisation, partial adjustment”, in I. Husain and R. Faruqee (eds). Adjustment in Africa. Lessons from country Case Studies, the World Bank, Washington DC: pp.286-351.

Reurink, A \& Garcia-Bernardo, J. 2020. Competing for capitals: the great fragmentation of the firm and varieties of FDI attraction profiles in the European Union, Review of International Political Economy, DOI: $\underline{10.1080 / 09692290.2020 .1737564}$

Rocheteau, G. 1982. Pouvoir Financier et indépendence economique en Afrique. Paris, Karthala

Rodney, W. 1972. How Europe Underdeveloped Africa. Bogle-L'Ouverture Publications.

Rowden. R. 2019. From the Washington Consensus to the Wall Street Consensus. Heinrich Böll Stiftung. Washington DC. https://us.boell.org/sites/default/files/rowden_wallstreetconsensus.pdf

Rönnbäck, K., and O. Broberg. 2019. Capital and Colonialism - The Return on British Investments in Africa 1869-1969. Cham, Switzerland: Palgrave MacMillan.

Searing, J.F., 1993. West African Slavery and Atlantic Commerce: The Senegal River Valley 1700-1860. Cambridge University Press, Cambridge

Shaw, E.S. 1973. Financial Deepening in Economic Development. New York: Oxford University Press.

Singh, Daleep 2008. Francophone Africa 1905-2005: A Century of Economic and Social Change. New Delhi: Allied Publishers Inc.

Smith, J. 2012. "Outsourcing, Financialization and the Crisis", International Journal of Management Concepts and Philosophy, 6 (1/2):19-44

Smith, J. 2016. Imperialism in the 21st Century. Globalization, Super-exploitation and Capitalism final crisis, New York: Monthly Review Press.

Sow, M. 1992. "Le crédit aux commerçants sénégalais", in: B. Barry and L. Harding. eds. Commerce et Commerçants en Afrique de l'Ouest, Paris: Harmattan.

Stockwell, S. E. 1998. Instilling the 'sterling tradition': Decolonization and the creation of a Central Bank in Ghana, The Journal of Imperial and Commonwealth History, 26:2, 100-119. 
Stockwell, S. E. 1995. Political strategies of British business during decolonization: The case of the Gold Coast/Ghana, 1945-57, The Journal of Imperial and Commonwealth History 23(2): 277-300.

Styve, M. D. 2019. From Marikana to London - The Anti-Blackness of Mining Finance. Thesis for the degree of Philosophiae Doctor (PhD), University of Bergen, Norway.

Suret-Canale, J. 1971. French Colonialism in Tropical Africa 1900-1945. New York. Pica Press

Sy, A. 2007. "Local Currency Debt Markets in the West African Economic and Monetary Union”, IMF working paper.

Sylla, N. \& Koddenbrock, K. 2019. Financialization in the West-African Monetary Union, African Agenda 22(2), 7-9.

Sylla, N.S. forthcoming. "Fighting Monetary Colonialism: Samir Amin's contribution", Review of African Political Economy

Tavares, M. 1985. A retomada da hegemonia Americana ['The Resumption of American Hegemony']Revista de Economia Politica 5(2): 5-16.

Taylor, A.A. 2006. An Economic History of the Ashanti Goldfields Corporation, 1895-2004: Land, Labour, Capital and Enterprise. PhD Thesis, London School of Economics and Political Science August 2006.

Taylor, I. 2015 'Dependency Redux: Why Africa is Not Rising', Review of African Political Economy 43(157): 8-25.

Teal, F. 1986. "The Foreign Exchange Regime and Growth: A Comparison of Ghana and the Ivory Coast", African Affairs 85(339): pp. 267-282

Tsikata, G. K. and G. K. Amuzu. 1993. "Fiscal Development Policies and Options." in V.K. Nyangteng (ed.) Policies and Options for Ghanaian Economic Development. University of Ghana: ISSER.

Tilley, L. 2020 Extractive investibility in historical colonial perspective: the emerging market and its antecedents in Indonesia, Review of International Political Economy, DOI: $\underline{10.1080 / 09692290.2020 .1763423}$

United Nations. 1992. "Net transfer of resources between developing and developed countries. Report of the Secretary-General", General Assembly, 14 September.

United Nations. 2011. World Economic Situation and Prospects 2011, New York, United Nations. United Nations. 2018. World Economic Situation and Prospects 2018, New York, United Nations 
Van-Helten, J. J. 1982. "Empire and High Finance: South Africa and the International Gold Standard 1890-1914", The Journal of African History 23 (4): 529-548.

White, N. J. 2017. "Imperial Business Interests, Decolonization, and Post-Colonial Diversification," in Oxford Handbook of the end of Empire, ed. Martin Thomas and Andrew Thompson. Oxford.

Wilks, I. 1975. Asante in the Nineteenth Century: The Structure and Evolution of a Political Order. Cambridge: Cambridge University Press. 